\title{
PEMBERDAYAAN PETUGAS LABORATORIUM UNTUK TERCIPTANYA LABORATORIUM Safety DI LINGKUNGAN UNIVERSITAS AIRLANGGA
}

\author{
Dani Nasirul Haqi, S.KM., M.KKK \\ Endang Dwiyanti, Dra., M.Kes \\ Mulyono, S.KM., M.Kes \\ Putri Ayuni Alayyannur, S.KM., M.KKK ${ }^{1) \text { a) }}$ \\ Fakultas Kesehatan Masyarakat, Universitas Airlangga \\ a)E-mail: putri_a_a@yahoo.com
}

\begin{abstract}
ABSTRAK
Terdapat 56 laboratorium kimia di Universitas Airlangga. Jumlah tersebut merupakan jumlah yang cukup banyak. Mengingat berbagai kegiatan mahasiswa dilakukan di laboratorium di berbagai fakultas di Universitas Airlangga dengan berbagai bahan kimia yang digunakan. Perlu dilakukan beberapa penyesuaian agar laboratorium kimia di Universitas Airlangga mampu menjadi laboratorium safety seperti penyusunan HIRADC. Pemberdayaan petugas laboratorium demi terciptanya laboratorium yang aman di lingkungan Universitas Airlangga dapat dilakukan dengan kegiatan workshop pembuatan HIRADC dan pendampingan pembuatan HIRADC. Kegiatan workshop pembuatan HIRADC merupakan kegiatan penyegaran kembali terkait penyusunan dokumen HIRADC. Hal ini dikarenakan sudah pernah dilakukan pemberian materi oleh pihak ketiga yang bekerja sama dengan Universitas Airlangga terkait pembuatan dokumen HIRADC. Pihak FKM melakukan pendampingan kepada setiap laboran dalam menyusun dokumen HIRADCnya. Pihak FKM mendatangi setiap laboratorium untuk menganalisis dokumen HIRADC yang sudah ada sebelumnya dan melakukan perbaikan sesuai dengan kondisi sebenarnya yang ada di setiap laboratorium.
\end{abstract}

Kata kunci: HIRADC, laboran, laboratorium

\section{PENDAHULUAN}

Laboratorium adalah tempat yang mempertemukan dosen, mahasiswa, dan peneliti dalam melakukan percobaan. Bekerja di laboratorium kimia tidak akan lepas dari kemungkinan bahaya dari berbagai jenis bahan kimia dan peralatan yang ada di dalamnya. Perlu dilakukan pemahaman dan kesadaran terhadap bahaya di laboratorium.

Banyak kecelakaan maupun luka yang terjadi serta kerusakan fasilitas kerja yang sangat mahal yang diderita oleh pengguna laboratorium saat bekerja. Semua kejadian tersebut sebenarnya dapat dihindari ataupun diminimalisasi dengan cara mengikuti prosedur kerja yang aman di laboratorium. Selain itu, petugas laboratorium harus melakukan analisis risiko dan mengkomunikasikan risiko tersebut kepada pengguna laboratorium.

Terdapat 56 laboratorium kimia di Universitas Airlangga. Jumlah tersebut merupakan jumlah yang cukup banyak. Mengingat berbagai kegiatan mahasiswa dilakukan di laboratorium di berbagai fakultas di Universitas Airlangga dengan berbagai bahan kimia yang digunakan. Perlu dilakukan beberapa penyesuaian agar laboratorium kimia di Universitas Airlangga mampu menjadi laboratorium safety seperti penyusunan HIRADC.
Tersedianya eye wash dan safety shower di laboratorium mendukung terciptanya safety laboratory. Namun kedua fasilitas tersebut tidak mungkin ada jika tidak dilakukan analisis risiko terlebih dahulu. Metode analisis risiko yang dilakukan di lingkungan Universitas Airlangga saat ini menggunakan metode HIRADC. HIRADC adalah kependekan dari Hazard Identification, Risk Assessment, and Determinant Control. Metode ini harus dilakukan di laboratorium untuk mengidentifikasi hazard yang ada, menganalisis besaran risikonya dan mengontrol factor determinan atau risiko sisa dari risiko yang sudah diminimalisasi. Setelah itu, perlu dilakukan komunikasi risiko yaitu mengkomunikasikan kepada seluruh pengguna laboratorium baik mahasiswa, dosen, maupun peneliti lain yang menggunakan laboratorium. Hal ini dikarenakan setiap laboratorium memiliki kekhasan risiko bahaya yang dimiliki.

Melakukan HIRADC tidak dapat dengan mudah dilakukan hanya dengan pembelajaran sekali. Perlu dilakukan pendampingan agar HIRADC yang disusun sesuai dengan risiko bahaya yang ada di laboratorium masing-masing. Selain itu, seluruh laboratorium kimia yang ada di lingkungan Universitas Airlangga menggunakan bahan kimia yang beraneka ragam. Untuk pengidentifikasiannya, setiap bahan kimia tersebut perlu dibuat safety data sheet-nya sehingga 
dapat diminimalisasi risikonya dan dilakukan penanganan yang sesuai dengan bahan kimia tersebut.

Mayoritas laboratorium di Universitas Airlangga belum memiliki dokumen HIRADC yang sesuai dengan kekhususan kegiatan dan bahaya yang ada di laboratoriumnya. Dokumen HIRADC dihasilkan hanya dalam beberapa hari tanpa melihat kondisi sebenarnya yang ada di lapangan. Oleh karena itu, perlu ada penyegaran kembali tentang penyusunan dokumen HIRADC dan pendampingan kegiatan penyusunan dokumen HIRADC agar sesuai dengan kegiatan yang dilakukan di setiap laboratorium.

\section{METODE}

Keamanan saat bekerja di laboratorium perlu diperhatikan. Terlebih apabila mahasiswa dalam jumlah yang banyak dan menggunakan bahan kimia serta alat laboratorium yang berbahaya. Keamanan saat melakukan kegiatan di laboratorium perlu ditunjang dengan adanya laboran yang peduli dan mengerti tentang keamanan di laboratorium.

Pemberdayaan petugas laboratorium demi terciptanya laboratorium yang aman di lingkungan Universitas Airlangga dapat dilakukan dengan beberapa kegiatan berikut:

a. Workshop pembuatan HIRADC.

b. Pendampingan pembuatan HIRADC.

Seluruh kegiatan tersebut merupakan rangkaian yang harus dilakukan agar sumber daya manusia yang bertanggung jawab terhadap keamanan laboratorium mampu melaksanakan tugasnya sesuai dengan tupoksi. Setelah itu, pihak laboran harus mensosialisasikannya kepada pengguna laboratorium baik mahasiswa maupun dosen agar mampu menerapkan dan menjaga keamanan selama menggunakan laboratorium.

\section{PEMBAHASAN}

Rincian kegiatan yang dilakukan dalam kegiatan pengabdian masyarakat pada tenaga laboran pada laboratorium di lingkungan Universitas Airlangga meliputi beberapa kegiatan, yaitu:

a. Workshop pembuatan HIRADC.

Kegiatan ini merupakan kegiatan penyegaran kembali terkait penyusunan dokumen HIRADC. Hal ini dikarenakan sudah pernah dilakukan pemberian materi oleh pihak ketiga yang bekerja sama dengan Universitas Airlangga terkait pembuatan dokumen HIRADC. Kegiatan ini dilakukan untuk mengingatkan kembali materi yang sudah disampaikan dan menambahkan hal-hal yang mungkin perlu ditambahkan. Pemateri dalam kegiatan ini merupakan staf pengajar dari Fakultas Kesehatan Masyarakat Universitas Airlangga yang memiliki pengalaman di bidang pembuatan HIRADC.
Dikarenakan menggunakan orang dalam sesama Unair, maka diharapkan laboran dapat berkomunikasi secara aktif kepada pembicara terkait hal-hal yang selama ini menjadi kesulitannya dalam menyusun dokumen HIRADC dan pengkomunikasinnya kepada seluruh pengguna laboratorium. Setelah kegiatan ini, diharapkan tidak ada hal-hal yang menjadi pertanyaan besar dari setiap laboran terkait HIRADC karena sudah dapat terpecahkan secara bersama-sama dalam kegiatan ini.

b. Pendampingan pembuatan HIRADC.

Setelah dilakukan workshop, maka pihak FKM melakukan pendampingan kepada setiap laboran dalam menyusun dokumen HIRADCnya. Pihak FKM mengutus satu staf pengajar beserta beberapa mahasiswa untuk ikut serta mendatangi setiap laboratorium. Hal ini untuk menganalisis dokumen HIRADC yang sudah ada sebelumnya dan melakukan perbaikan sesuai dengan kondisi sebenarnya yang ada di setiap laboratorium.

Kegiatan pendampingan ini dilakukan sebanyak 4 kali. Pendamping beserta laboran dapat melakukan pertemuan secara rutin di luar jadwal yang ditentukan. Hal ini dikarenakan kegiatan pemakaian setiap laboratorium tidak hanya 4 kali dalam seminggu. Analisis risiko dalam rangka penyusunan dokumen HIRADC akan lebih sesuai dengan kondisi jika dilakukan saat laboratorium digunakan kegiatan praktikum. Pada kegiatan praktikum, berbagai jenis kegiatan dan risiko bahayanya dapat teridentifikasi secara mendetail. Hal ini berbeda jika analisis risiko hanya dilakukan melalui teknik wawancara kepada laboran atau dosen pengampu saja. Pengkomunikasian dokumen HIRADC juga perlu dilakukan. Hal ini agar setiap pengguna laboratorium mengetahui risiko bahaya yang ada di laboratorium tersebut dan cara penanganan untuk meminimalisasi adanya risiko bahaya tersebut. Dokumen HIRADC tidak hanya tertumpuk begitu saja di dalam almari ruangan laboratorium. Pada kegiatan pendampingan yang terakhir, dilakukan evaluasi terhadap setiap HIRADC dan cara mengkomunikasikannya kepada setiap pengguna. Hal ini dilakukan untuk mendapatkan masukan metode yang tepat dalam mengkomunikasikan HIRADC dan mengetahui kesiapan setiap laboran di lingkungan Universitas Airlangga dalam memperbarui HIRADCnya secara rutin setiap tahun atau ketika ada kegiatan baru di laboratoriumnya yang belum tercatat di HIRADC.

\section{PENUTUP}

\section{Kesimpulan}

Kesimpulan dalam kegiatan ini adalah pemberdayaan petugas laboratorium demi terciptanya laboratorium yang aman di lingkungan Universitas Airlangga dapat dilakukan dengan beberapa kegiatan: 
a. Workshop pembuatan HIRADC.

b. Pendampingan pembuatan HIRADC.

\section{Saran}

Saran yang kami berikan dalam perbaikan kegiatan pengabdian masyarakat khususnya terkait laboratorium yang aman adalah:

a. Perlu adanya penyebarluasan hasil pendampingan kepada laboratorium lain dalam fakultas yang sama yang tidak mendapatkan kesempatan untuk didampingi dalam pembuatan HIRADC.

b. Perlu adanya tenaga khusus K3 di setiap fakultas.

\section{REFERENSI}

Mudzkirah, Ida. 2016. Identifikasi Penggunaan Zat Pengawet Boraks dan Formalin Pada Makanan Jajanan di Kantin UIN Alauddin Makassar Tahun 2016. Fakultas Kedokteran dan Ilmu Kesehatan Universitas Islam Negeri Alauddin Makassar. http://repositori.uinalauddin.ac.id/1122/1/Ida\%20Mudzkirah.PDF. Diakses pada 19 Mei 2018
Peraturan Menteri Kesehatan Republik Indonesia Nomor 1096 Tentang Higiene Sanitasi Jasaboga. http://jdih. pom.go.id/showpdf.php? $\mathrm{u}=\% 2 \mathrm{FeEhdLEZt4PPcLAIa}$ af\%2BQtIfapCyf3NuoAc\%2BvZapIG4\%3D. Diakses pada 19 Mei 2018

Peraturan Menteri Ketenagakerjaan Republik Indonesia Nomor 12 Tahun 2015 Tentang Keselamatan dan Kesehatan Kerja Listrik di Tempat Kerja.

Rachmiyati, Sri. 2008. "The Effectiveness Of Laboratory Use In Madrasah Aliyah In Yogyakarta”. Jurnal Penelitian dan Evaluasi Pendidikan, Nomor 1, Tahun XI, 2008. [online] https://journal.uny.ac.id/index.php/jpep/article/ viewFile/1420/1208 diakses pada tanggal 19 Mei 2018

Satriawan, LA. 2009. Skripsi. [online] http://e-journal.uajy. ac.id/3052/3/2TS11587.pdf diakses pada tanggal $19 \mathrm{Mei}$ 2018

Undang-Undang Nomor 23 Tahun 2002 Tentang Bangunan Gedung. http://eodb.ekon.go.id/download/peraturan/ undangundang/UU_28_2002.pdf. Diakses pada $19 \mathrm{Mei}$ 2018

Vendamawan, Rico. 2015. "Pengelolaan Laboratorium Kimia”. Jurnal Metana, Vol. 11 No. 02, Desember 2015, Hal. 41 - 46. [online] https://ejournal.undip.ac.id/index. $\mathrm{php} / \mathrm{metana} /$ article/download/14757/11251 diakses pada tanggal 19 Mei 2018 